\title{
Violent crimes in native and foreign national offenders
}

\author{
Karin Arbach-Lucioni ${ }^{\text {a,* }}$, Santiago Redondo-Illescas ${ }^{\text {a }}$, Jay P. Singh ${ }^{\mathrm{b}}$, \\ Antonio Andrés-Pueyo ${ }^{a}$
}

${ }^{a}$ Advanced Studies in Violence Group, University of Barcelona, 171 Passeig Vall d'Hebron, Barcelona 08035, Spain

${ }^{\mathrm{b}}$ Department of Mental Health Law and Policy, University of South Florida, 13301 Bruce B. Downs Blvd, Tampa, FL 33612, USA

\begin{abstract}
Although the foreign national population in Spanish prisons has doubled during the past decade from $22 \%$ to $44 \%$, few studies have investigated the contribution of foreign nationals to criminality and their risk profiles compared to natives. The present paper compared rates of violent conviction in 917 native and 657 foreign national male offenders, and explored differences in risk factors for violence between groups using logistic regression, receiver operating characteristic (ROC) curve analysis, and positive and negative predictive values (PPV and NPV, respectively). Natives and foreign nationals showed no significant differences in the rate of violent conviction $(19.6 \%$ vs. $17.2 \%$, respectively). However, when multivariate models were developed to predict violence in the samples using logistic regression, between-group differences in the risk profiles of violent and non-violent offenders were found. Implications of the findings for research, public policy and risk management were explored.

(c) 2014 Elsevier Ltd. All rights reserved.
\end{abstract}

Keywords: Risk factor; Violence; Immigration; Area under curve; Offender

\section{Introduction}

The scientific study of the relationship between mass immigration and violent crime has a long tradition in sociology and criminology, dating from the classic work of the Chicago School (Shaw and McKay, 1997 [1942]). In the United States and in most European countries, foreign

\footnotetext{
* Corresponding author.

E-mail addresses: karinarbach@psyche.unc.edu.ar, karinarbach@ub.edu (K. Arbach-Lucioni).
} 
nationals are currently overrepresented in police, court and prison statistics (Ellis et al., 2009). The most commonly accepted interpretation of this trend is that mass immigration contributes to increased crime figures, due to its perceived exacerbation of criminogenic conditions such as poverty, social disorganization, and dilution of social control (Lee et al., 2001; Martinez, 2002). Immigration could also lead to higher crime rates by increasing a nation's male population aged 15-30 years, which contains the greatest concentration of offenders (Alonso et al., 2008). For example, in 2010, 20.4\% of foreign nationals in Catalan prisons have less than 25 compared with $9.8 \%$ of natives (Catalan Justice Department, 2011). Alternatively, increased immigration rates could result in increased rates of unemployment among foreign nationals, potentially increasing criminal motivation (Alonso et al., 2008). In this respect, Spain's 2010 unemployment rate for foreign nationals $(30 \%)$ was approximately twice that of native Spaniards (18\%) (INE, 2010a), suggesting that the proportion of attributable risk for offending might be higher in immigrants.

In contrast to prevailing public attitudes claiming a positive association between immigration and crime (Hagan et al., 2008), it has recently been suggested that foreign nationals' higher rates of recorded criminality may be reflective of systematic criminal justice biases (Banks, 2011; Horton, 2002). That is, foreign nationals may not commit more offenses than natives but, rather, be more easily identified by victims, perceived as more blameworthy, and seen as a greater threat to public safety (Killias et al., 2011; McGovern et al., 2009). Recent investigations have not found clear evidence of an association between immigrant status and crime after controlling for demographic and economic factors (Ousey and Kubrin, 2009; Reid et al., 2005), suggesting that foreign nationals are no more likely to commit violent acts than natives (Horton, 2002; Rumbaut and Ewing, 2007).

When examining violent crime rates in urban centers, several large-scale studies have found higher concentrations of foreign nationals to be associated with decreased crime rates (Martinez, 2002, 2010; Martinez et al., 2010; Sampson, 2008; Sampson et al., 2005; Wright and Benson, 2010). National statistics in the United States and Spain support these findings: An analysis by the Immigration Policy Center (2008) found that the US foreign national population increased 50\% over the period 1994-2005, while the rate of violent crime fell by $34.2 \%$. In Spain, the foreign national population increased in the period 2002-2008 from $3.2 \%$ to $9.8 \%$ (Rumí Ibáñez, 2008), while the rate of violent crime decreased by 3.3\% (Tavares and Thomas, 2010).

\subsection{Risk factors for violent crimes in natives versus foreign nationals}

Risk factors are those biological, psychological, and sociological characteristics that systematically increase the likelihood of future offending (Singh, 2012). When differences in rates of violent crime between natives and foreign nationals are found, they are routinely attributed to socio-demographic risk factors such as poverty, unemployment, the marital status of parents, inequality, or dimensions of the neighborhood social context (Felson et al., 2008; Land et al., 1990; Nivette, 2011; Sampson et al., 2005; Hagan and Palloni, 1999). Some evidence suggests that while a number of factors present in immigrant groups such as single-parent families and lower educational attainment increase violence risk, other factors such as religiosity, strong family ties, and low alcohol consumption decrease this risk (Pratt and Godsey, 2002; Wright and Younts, 2009).

Social support has been proposed as a protective factor against violent behavior and crime in immigrant communities (Pratt and Godsey, 2002; Wright and Cullen, 2001). The collective 
social protection and cohesion that minority communities offer to their members may cushion the possible effect of economic inequality have on violence and homicide (Feldmeyer, 2009; Martinez, 2002; Savolainen, 2000).

Also, violent behaviour inside prisons has been studied in relation to immigration. Prior findings in the Catalan prison system have found that foreign national inmates show a lower rate of involvement in riots (at an average of 0.5 incidents by inmate and year) than native inmates (1.6 incidents) (Area of Social and Criminologic Research and Training, 2010). In contrast, prospective research has found no significant differences across groups: $8 \%$ of natives and $9.6 \%$ of foreign nationals show at least one violent behaviour in prison (assault, battery, and/or serious threats) during a ten-month follow-up period (Arbach-Lucioni et al., 2012).

Finally, variables such as attitudes towards crime, response to treatment or self-harm behaviors have been studied in relation to criminal behavior (Andrews and Bonta, 1995; Crutchfield and Pettinicchio, 2009; Gendreau et al., 1996). They are included in the present study in order to explore their differential relationship with violent crimes in natives and foreign national offenders.

\subsection{The present study}

Although public opinion deduces that rates of immigration and violent crime are positively associated, a growing body of evidence suggests that this may not be the case (Lee et al., 2001; Martinez, 2002; Rumbaut and Ewing, 2007; Sampson, 2008; Stowell and Martínez, 2007). To further investigate, the present study compared the crime rates and predictors of violence in Spanish natives and foreign nationals.

\section{Method}

\subsection{Sample}

The sample was composed of 1574 convicted males $\left(n_{\text {Foreign }}\right.$ National $=657$ and $n_{\text {Native }}=917$ ), who were randomly selected from a cohort of inmates whose violence risk was assessed using a recently implemented screening instrument, the RisCanvi-S (or "risk assessment for change" in Catalan) (Andrés-Pueyo et al., 2010). The sample represented 16.8\% of the prison population of Catalonia, a region in the northeast of Spain with a population of approximately 7,500,000 inhabitants (INE, 2010b), 16.0\% of whom are foreign nationals. The Catalan correctional system had an average prison population of 10,741 inmates at the time of sampling (Catalan Justice Department, 2011). The distribution of foreign nationals to natives (41.7\% and 58.3\%, respectively) was similar to that of the nationality distribution in the total prison population $(43.8 \%$ and $56.2 \%$, respectively). Foreign nationals emigrated from 63 countries, most commonly Morocco (12.5\%), Colombia (3.2\%), Ecuador (3.0\%), and Romania $(2.3 \%)$.

\subsection{Measures}

Information on socio-demographic, criminal history, and imprisonment-related factors were gathered from RisCanvi assessments and the electronic prison information system of the Justice Department of Catalonia from July 1, 2009 to October 31, 2010. The association 
between these three categories of information and violence in natives versus foreign nationals was investigated. Socio-demographic factors of interest included: age (in years), marital status (single versus in a relationship), economic resources (assets and incomes of the participant and family members used to cover costs of living over the past 12 months), and social support (a stable social network of relatives and friends over the past 12 months).

Criminal history factors included age at onset of criminality (17 years-old was the cutoff according the age-crime curve; Farrington, 1986), lifetime history of community violence (including officially recorded and self-reported violence), drug (including alcohol) use problems over the past 12 months inside prison or in prison' leaves, and attitudes towards criminality (covering as well the subject's justifications of crimes as defined in the Andrews \& Bonta's model as a pattern of hostile behaviors).

Offenders' experiences of arrest, formal processing into the justice system, and imprisonment may be, in themselves, risk factors for future violence (Bernard et al., 2010). Therefore, imprisonment characteristics were investigated as potential risk factors for violence in the present research. Imprisonment factors included prison adjustment (disciplinary infractions and overt adjustment problems records), behavior on previous status orders (evasions, escapes or other sentence infringement), response to treatment over the past 12 months, and history of selfharm (including suicide attempts). All factors, with the exception of age, were measured categorically. Table 1 shows the frequency distribution of the characteristics in natives versus foreign nationals.

To compare the risk profiles of native and foreign national serious offenders, conviction for a violent offense was considered as the dependent variable in the present investigation. Violence was operationally defined as a conviction for homicide, robbery, assault, and battery. Sexual violence was excluded, as it represents a highly specific criminal typology.

Table 1

Sample characteristics: Native and foreign national offenders comparison.

\begin{tabular}{|c|c|c|c|}
\hline & Natives & Foreign nationals & $\chi^{2}$ \\
\hline & $n=917$ & $n=657$ & \\
\hline \multicolumn{4}{|l|}{ Socio-demographic factors } \\
\hline Mean age (SD) & $38.2(9.7)$ & $32.8(11.6)$ & $*^{\mathrm{a}}$ \\
\hline Marital status (single) & 82.9 & 72.8 & $*$ \\
\hline Economic resources (low) & 23.4 & 36.8 & $*$ \\
\hline Social support (low) & 14.1 & 30.3 & $*$ \\
\hline \multicolumn{4}{|l|}{ Criminal history factors } \\
\hline Early onset of criminality (yes) & 14.2 & 8.1 & $*$ \\
\hline History of violence (yes) & 54.6 & 37.0 & $*$ \\
\hline Drug use problems (yes) & 37.3 & 16.7 & $*$ \\
\hline Attitudes to criminality (pro-criminal) & 24.2 & 16.7 & $*$ \\
\hline \multicolumn{4}{|l|}{ Imprisonment factors } \\
\hline Prison adjustment (maladjustment) & 44.1 & 42.0 & ns \\
\hline Behavior on previous orders (violations) & 38.3 & 18.4 & $*$ \\
\hline Response to treatments (poor) & 29.9 & 11.9 & $*$ \\
\hline History of self-harm (yes) & 18.9 & 8.5 & $*$ \\
\hline
\end{tabular}

Note: $n$, number of participants; $\mathrm{SD}$, standard deviation; ns, non-significant.

$* p<.001$.

a $t$-Test. 


\subsection{Procedure and analysis}

Natives and foreign nationals were compared across all factors for which information was collected. A $\chi^{2}$ test of association was used to explore whether the rate of violent conviction and frequency distribution of factors differed between the subgroups.

Univariate logistic regression analyses were used to investigate the predictive utility of each of the factors of interest in natives and foreign nationals considering violent and non-violent subgroups. Two multivariate models were then developed including only those factors associated with violent conviction at the $p<.05$ level in univariate analyses.

Areas under the receiver operating characteristic (ROC) curve and their standard errors were calculated. ROC curve analysis quantifies the trade-off between sensitivity and specificity across all possible cutoff scores of a predictive model. Sensitivity concerns the proportion of individuals convicted of a violent offense who the predictive model correctly classified as being at high risk of violence. By contrast, specificity refers to the proportion of individuals convicted of a non-violent offense that the predictive model correctly classified as being at low risk of violence. The area under the ROC curve (AUC) is equivalent to the probability that a randomly selected violent offender had a higher score than a randomly selected non-violent offender (Mossman, 1994). The AUC is commonly used for summarizing the overall discriminating power of predictive models, as it is resistant to changes in both base rate and selection ratio (Rice and Harris, 2005). As the AUC does not discriminate between predictive models that perform well in identifying high versus low risk individuals, the positive and negative predictive values (PPV and NPV, respectively) were also calculated. PPV is the proportion of individuals who the model classified as being at high risk of violence who were convicted of a violent offense, whereas NPV is the proportion of individuals the model classified as being at low risk of violence who were not convicted of a violent offense.

\section{Results}

The sample was composed of 1574 incarcerated males, $18.6 \%$ of whom had been convicted of a violent offense. Native and foreign national offenders had non-significantly different rates of violent conviction $\left(19.6 \%\right.$ vs. $17.2 \%$, respectively), $\chi^{2}(1, N=1574)=1.49, p=.22$. Table 1 compares the frequency distribution of socio-demographic, criminal history, and imprisonment characteristics of interest between natives and foreign nationals.

\subsection{Univariate analyses}

The frequency distribution of the factors shows differences in the risk profiles of violent and non-violent offenders (Table 2). The non-violent group shows the same differences registered in the total sample, and these differences tend to disappear in the violent group where any criminal history factors were found to differentiate natives and foreign nationals. Age and economic resources differentiated foreign nationals, whereas behavior on previous status orders, response to treatments, and a history of self-harm differentiated Spanish natives.

\subsection{Multivariate analyses}

Those risk factors identified at the $p<.05$ level in the univariate analyses were combined to develop two multivariate prediction models, one for each subgroup of offenders (Table 3). The 
Table 2

Comparison of frequency distribution of factors in violent and non-violent offender groups between natives and foreign nationals.

\begin{tabular}{|c|c|c|c|c|c|c|c|c|c|c|}
\hline & \multicolumn{5}{|c|}{ Violent offenders } & \multicolumn{5}{|c|}{ Non-violent offenders } \\
\hline & Natives & $\begin{array}{l}\text { Foreign } \\
\text { nationals }\end{array}$ & & & & Natives & $\begin{array}{l}\text { Foreign } \\
\text { nationals }\end{array}$ & & & \\
\hline & $n=180$ & $n=113$ & & & & $n=737$ & $n=544$ & & & \\
\hline $\begin{array}{l}\text { Socio-demographic } \\
\quad \text { factors }\end{array}$ & $\%$ & $\%$ & $\chi^{2 \mathrm{a}}$ & OR & $95 \% \mathrm{CI}$ & & & $\chi^{2 \mathrm{a}}$ & OR & $95 \% \mathrm{CI}$ \\
\hline Mean age (SD) & $\begin{array}{l}39.3 \\
(11.1)\end{array}$ & $\begin{array}{l}33.5 \\
(8.9)\end{array}$ & $* * *$ & .94 & $.92-.97$ & $\begin{array}{l}37.9 \\
(11.7)\end{array}$ & $\begin{array}{l}32.6 \\
(9.8)\end{array}$ & $* * *$ & .96 & $.95-.97$ \\
\hline Marital status (single) & 82.8 & 75.2 & ns & .63 & $.36-1.12$ & 82.9 & 72.2 & $* * *$ & .54 & $.41-.70$ \\
\hline $\begin{array}{l}\text { Economic resources } \\
\text { (low) }\end{array}$ & 16.1 & 31.9 & $* *$ & 2.43 & $1.39-4.23$ & 25.2 & 37.9 & $* * *$ & 1.81 & $1.42-2.30$ \\
\hline Social support (low) & 19.4 & 28.3 & ns & 1.64 & $.94-2.84$ & 12.8 & 30.7 & $* * *$ & 3.03 & $2.28-4.02$ \\
\hline \multicolumn{11}{|l|}{ Criminal history factors } \\
\hline $\begin{array}{l}\text { Early onset of } \\
\text { criminality (yes) }\end{array}$ & 15.0 & 9.7 & ns & .61 & $.29-1.29$ & 14.0 & 7.7 & $* * *$ & .51 & $.35-.75$ \\
\hline History of violence (yes) & 97.2 & 92.9 & ns & .38 & $.12-1.18$ & 44.2 & 25.4 & $* * *$ & .43 & $.34-.55$ \\
\hline Drug use problems (yes) & 38.3 & 28.3 & ns & .64 & $.38-1.06$ & 37.0 & 14.3 & $* * *$ & .28 & $.21-.38$ \\
\hline $\begin{array}{l}\text { Attitudes to criminality } \\
\text { (pro-criminal) }\end{array}$ & 35.6 & 33.6 & ns & .92 & $.56-1.51$ & 21.4 & 13.2 & $* * *$ & .56 & $.41-.76$ \\
\hline \multicolumn{11}{|l|}{ Imprisonment factors } \\
\hline $\begin{array}{l}\text { Prison adjustment } \\
\text { (maladjustment) }\end{array}$ & 41.7 & 38.9 & ns & .89 & $.55-1.44$ & 44.6 & 42.6 & ns & .92 & $.74-1.15$ \\
\hline $\begin{array}{c}\text { Behavior on previous } \\
\text { orders (violations) }\end{array}$ & 47.8 & 29.2 & $* *$ & .45 & $.27-.74$ & 36.0 & 16.2 & $* * *$ & .34 & $.26-.45$ \\
\hline $\begin{array}{l}\text { Response to treatments } \\
\text { (poor) }\end{array}$ & 35.8 & 22.5 & $*$ & .55 & $.30-.90$ & 28.5 & 9.8 & $* * *$ & .27 & $.20-.38$ \\
\hline $\begin{array}{l}\text { History of self-harm } \\
\text { (yes) }\end{array}$ & 22.2 & 12.4 & $*$ & .50 & $.26-.96$ & 18.1 & 7.7 & $* * *$ & .38 & $.26-.55$ \\
\hline
\end{tabular}

Note: $n$, number of participants; $\mathrm{SD}$, standard deviation; ns, non-significant.

$* p<.05 ; * * p<.01 ; * * * p<.001$.

${ }^{\mathrm{a}} t$ Test.

factor lifetime history of community violence was removed from the analyses because a violent conviction offense was included in the definition which increased its predictive power in the violent group to the detriment of the remaining factors. Pro-criminal attitudes and violations of previous orders were common predictors in both groups. Natives with pro-criminal attitudes were twice more likely to have engaged in a violent crime compared with natives without the risk factor present. This risk was three times higher in foreign nationals with pro-criminal attitudes. The presence of violations of previous orders increased risk for violent offenses by $60 \%$ in both samples. Additionally, subgroup-specific risk factors were also identified. While the lack of economic resources decreased the likelihood of having a conviction for a violent offense by $56 \%$, the lack of social support doubled the risk for native offenders. Foreign national offenders with a poor response to treatments in the last year showed a two-fold risk of violent offenses.

Hosmer-Lemeshow tests evidenced goodness of fit for both models when used to predict violent conviction $(p>.05)$. Table 4 displays the performance indices of the two models. The predictive schemes produced AUCs above chance with a trend towards higher negative 
Table 3

Risk factors for violent crime in the samples of natives and foreign nationals derived from multivariate regression analyses.

\begin{tabular}{|c|c|c|c|c|c|c|}
\hline \multirow[t]{2}{*}{ Factors in the model } & \multicolumn{3}{|l|}{ Natives } & \multicolumn{3}{|c|}{ Foreign nationals } \\
\hline & $\beta$ & OR & $95 \% \mathrm{CI}$ & $\beta$ & OR & $95 \% \mathrm{CI}$ \\
\hline Lack of economic resources & $-.91 * * *$ & .40 & $.25-.65$ & & & \\
\hline Lack of social support & $.72 * *$ & 2.05 & $1.26-3.35$ & & & \\
\hline Violations of previous orders & $.45 * *$ & 1.56 & $1.11-2.19$ & $.50 *$ & 1.65 & $1.01-2.71$ \\
\hline Pro-criminal attitudes & $.62 * * *$ & 1.86 & $1.29-2.67$ & $1.06 * * *$ & 2.88 & $1.78-4.66$ \\
\hline Poor response to treatments & & & & $.70 *$ & 2.00 & $1.15-3.50$ \\
\hline
\end{tabular}

$* p<.05 ; * * p<.01 ; * * p<.001$.

predictive values. As expected, the AUC values improved significantly when the factor history of violence, initially removed from the analyses, was considered in the model (AUC $=.82$ [95\% $\mathrm{CI}=.79-.85]$ in natives, and $\mathrm{AUC}=.87[95 \% \mathrm{CI}=.83-.90]$ in foreign nationals).

\section{Discussion}

The relationship between immigration and crime has been a source of major debate throughout the past century, with mixed evidence as to whether increased foreign national populations result in increased rates of violent crime and if this population has specific risk factors that predisposed them to violent crimes (Reid et al., 2005; Sampson, 2008; Sampson et al., 2005; Vazsonyi and Killias, 2001; Wright and Benson, 2010). The present investigation explores differences in the rate of violent crimes and the risk factors associated with them in a randomly selected cohort of 1574 native and foreign national male offenders.

Results show no evidence of differences in the rate of violent conviction, tough they show differences in the distribution of risk factors in each nationality group. In general, results suggest that Spanish natives have more risk factors than foreign nationals, at least among individuals assessed for violence risk using the screening tool addressed in this paper. Also, global results show more differences between native and foreign national non-violent offenders than in violent offenders. Finally, results show that while shared risk factors exists for violent crimes, a set of unique risk factors can be identified in each group.

\subsection{Comparison with previous research}

In general terms, foreign national inmates tend to show more socio-demographic risk factors (they were younger and had lower economic resources and lower social support) which is in

Table 4

Predictive accuracy of the models for native and foreign national offenders.

\begin{tabular}{lccc}
\hline & Effect size & & \\
\cline { 2 - 4 } & PPV & NPV & AUC (95\% CI) \\
\hline Natives & .27 & .86 & $.65(.60-.69)^{*}$ \\
Foreign nationals & .29 & .89 & $.67(.61-.73)^{*}$ \\
\hline
\end{tabular}

Note: PPV, positive predictive value; NPV, negative predictive value; AUC, area under the curve; CI, confidence interval.

$* p<.001$. 
line with previous results for offender (Felson et al., 2008) and community samples (Alonso et al., 2008; Land et al., 1990; Lee et al., 2001; Martinez, 2002). It also reflects what happens in the general community since statistical data at the national level show that the proportion of foreign national men aged 15-29 years is twice that of natives (INE, 2010b). A similar increase occurs in the immigrant unemployment rate compared with natives (INE, 2010a) and this is strongly related with economic deprivation in the former group (Alonso et al., 2008; Hagan and Palloni, 1999).

In turn, native offenders tend to show significantly more criminal and imprisonment risk factors with the sole exception of prison maladjustment which, as in previous research (ArbachLucioni et al., 2012), shows no differences across groups.

Another issue to address was to determine whether native and foreign offenders shared a pattern of risk factors for specific types of criminal behavior (i.e. violent and non-violent crimes). To explore the earlier results in more detail, the sample was split into violent and non-violent offenders' groups. Then native and foreign national offenders were compared within each group. While non-violent group maintain the differences observed in the total sample, differences between natives and foreign nationals tend to dispel in the violent group, especially those in the criminal history factors. Although prior literature have explored crime predictors extensively (Andrews and Bonta, 1995; Gendreau et al., 1996) we were not able to found results that help to explain these results.

In a second stage of analyses, multivariate regression was use to test the null hypothesis that no difference could be expected between Spanish natives and foreign nationals in the factors associated with the commission of violent offenses. The null hypothesis was partially confirmed, since two risk factors emerged as common correlates of violent crime for both native and foreign offenders: pro-criminal attitudes and violations of previous orders. Empirical evidence addresses the link between pro-criminal attitudes and violent offending (Andrews and Bonta, 1995). Additionally, both variables are strongly related to each other in practice, and also they were in analysis, because the former factor doubled the likelihood of having a history of orders violations, which by definition implies a lack of consideration for established rules. The size effect of pro-criminal attitudes was higher in foreign nationals than in natives, which suggests that for former personality characteristics are better predictors of violent behavior than demographic features. The finding that a poor response to treatments doubles the risk among foreign nationals supports this idea, since the treatments included in this item focus on behavioral, cognitive and emotional characteristics associated with criminal behavior.

Native offenders showed two specific risk factors that had an opposite influence on each other. On one hand, the aggregate variable economic resources decreased the risk for violent crime. Although this finding may seem counterintuitive in light of many studies linking economic deprivation to criminal behavior (Felson et al., 2008; Land et al., 1990; Nivette, 2011; Sampson et al., 2005; Vazsonyi and Killias, 2001), it may be understood in light of evidence that economic problems have been found to be positively associated with other typologies of crime, such as those related to illegal drug markets (crimes against public health) or property offenses, which are precisely those included in the comparison group (Stowell, 2007). Inversely, lack of social support was the strongest predictor of violent offenses in this group, more than doubling the risk of violent criminal activity. Previous studies support this finding (Colvin et al., 2002; Pratt and Godsey, 2002; Wright and Cullen, 2001) and suggest that the social cohesion of immigrant communities may act as a protective factor against violent criminal activity (Feldmeyer, 2009; Martinez, 2002; Savolainen, 2000; Wright and Younts, 2009). 
Variables such as age, criminal history, and substance abuse that did not enter in the regression solution could be more directly associated with general criminality (i.e. violent and non-violent crimes) than with a specific type of crime. Andrews and Bonta (1995) put them among the major risk factors for general criminal behavior, and they have been shown in metaanalyses to be significant and powerful predictors of both general and violent recidivism (Gendreau et al., 1996).

\subsection{Implications}

The data reviews in this article are useful for reflecting on criminal law policies and the findings have implications for the treatment and rehabilitation approaches used on offenders. The official data on crime rates and immigrant population suggest that the overrepresentation of immigrants in Spanish prisons may be a result of biases in the criminal justice system, which have already been identified in the US (Felson et al., 2008) and the UK (Banks, 2011). This is feasible because more foreign nationals than natives in prison are serving a sentence for drugtrafficking crimes (39\% vs. $18 \%$, respectively) which entail long prison stays, possibly longer than for many violent crimes. There are also more foreign national offenders in preventive prison compared with natives (29\% vs. $13 \%$, respectively), which could delay the obtaining of prison benefits such as a third-grade classification (at the community level) or access to treatments to reduce their risk, benefits that would reduce time in prison. As a result, these many biases could be strengthening the criminogenic effects on this group that some authors have attributed to the process of prisonization (Braithwaite, 2000; Clemmer, 1990; Maruna et al., 2004).

In relation to the case management of offenders, the actual practice of administering standardized treatment programs to prisoners convicted of violent offenses fails to consider differences across inmates' cultural background. Although these programs have shown efficacy in reducing the risk of reoffending by focusing on relevant risk factors in the general offender population, the uniformity of programs could be less effective in terms of adherence if ethnic and cultural aspects are not considered. In the case of native offenders, results suggest that interventions directed at improving the social resources of inmates and increasing their adherence to supervision could be helpful in the reduction of risk. By contrast, psychologicallyoriented interventions, such as cognitive therapy directed at reducing pro-criminal attitudes and antisocial personality traits seems to be indicated to reduce risk in foreign national offenders, although language differences remain a major barrier for gaining access to treatments in this population.

\subsection{Limitations and future research}

These results need to be considered in light of some limitations of the study. The immigrant status did not consider the offenders' generation or country of origin and in consequence important differences within the immigrant population are overlooked. Some findings suggest that when ethnic-specific measures of immigration are considered a combination of negative and null effects from the presence of foreign-born ethnic groups on violent crime are found (Stowell, 2007; Stowell and Martínez, 2007). Even more, previous studies found differences among the population of the same ethnicity (Felson et al., 2008). Future research should include country of origin as a mediator variable to catch cultural differences across groups. Also, forthcoming studies should consider the generation level of immigrants since some results 
obtained in the US (Eyal Press, 2006; Sampson et al., 2005), in Spain and other European countries find a lower propensity to commit criminal offenses among newly-arrived immigrants (Alonso et al., 2008) in comparison to natives and subsequent generations of immigrants (Vazsonyi and Killias, 2001).

Also, a longitudinal design is needed to identify real predictors of violent crime. Devising a true prospective model would offer an opportunity to improve this research. The low PPVs of the predictive models were probably due to the low base rate and point out the difficulty in predicting low base rate behaviors (Szmukler, 2001). The figures suggest that predictive models obtained were useful in identifying individuals who have not committed a violent crime, more than identifying violent individuals. However, this cross-sectional approach is a first step toward detecting how those variables are differently related to the outcome in the subgroups studied. The results reported here are not irrelevant to the many, and strongly causal, claims that immigration increases crime and poses a much greater risk to communities than the native-born (Sampson, 2008).

\section{Conclusions}

In resume, only a thorough study of epidemiological and correctional data and legal regulations will serve to draw general conclusions about the relationship of mass immigration and crime in Spain. However, the descriptive results of this study indicate that natives and immigrants in prison have similar rates of violent crime and a differential criminal risk pattern. Offender treatments aimed at reducing the likelihood of violent recidivism should take into account that, although natives and immigrants have similar rates of conviction for such crimes, risk factors could vary by origin and in consequence, treatments and rehabilitation efforts should be adapted to improve adherence and preventive efficacy.

\section{References}

Alonso, C., Garoupa, N., Perera, M., Vázquez, P., 2008. Immigration and Crime in Spain, 1999-2006. Fundación de Estudios de Economía Aplicada, Madrid.

Andrés-Pueyo, A., Arbach, K., Redondo-Illescas, S., 2010. Report on the Development of the RisCanvi Protocol and the Scales for Assessing the Violence Risk for Violent Offenders (Technical report). Department of Justice of the Catalan Government, Barcelona.

Andrews, D., Bonta, J., 1995. The Psychology of Criminal Conduct. Anderson Publishing, Cincinatti.

Arbach-Lucioni, K., Martínez-García, M., Andrés-Pueyo, A., June 11, 2012. Risk factors for violent behavior in prison inmates: a cross-cultural contribution. Crim. Justice Behav. http://dx.doi.org/10.1177/0093854812445875.

Arbach, K., Martinez-García, M., Andrés-Pueyo, A., 2012. Risk factors for violent behavior in prison inmates: a crosscultural contribution. Criminal Justice and Behavior 39 (9), 1219-1239.

Area of Social and Criminologic Research and Training, 2010. Estrangers a les presons catalanes. Centre d'Estudis Jurídics i Formació Especialitzada. Departament de Justicia de Catalunya, Barcelona.

Banks, J., 2011. Foreign national prisoners in the UK: explanations and implications. Howard J. 50 (2), $184-198$.

Bernard, T.J., Snipes, J.B., Gerould, A.L., 2010. Vold's Theoretical Criminology. Oxford University Press, New York.

Braithwaite, J., 2000. Shame and criminal justice. Can. J. Criminol. 42 (3), 281-298.

Catalan Justice Department, 2011. Descriptors estadístics de Serveis Penitenciaris i Rehabilitació. Secretaria de Serveis Penitenciaris, Rehabilitació i Justícia Juvenil. Generalitat de Catalunya, Barcelona.

Clemmer, P., 1990. The Prison Community. Christopher Publishing, Boston.

Colvin, M., Cullen, F.T., Vander Ven, T., 2002. Coercion, social support, and crime: an emerging theoretical consensus. Criminology 40 (1), 19-41.

Crutchfield, R.D., Pettinicchio, D., 2009. Cultures of inequality: ethnicity, immigration, social welfare, and imprisonment. Ann. Am. Acad. Polit. Soc. Sci. 623, 134-147. 
Ellis, L., Beaver, K., Wright, J., 2009. Handbook of Crime Correlates. Elsevier Inc, San Diego, CA.

Eyal Press, 2006. Do immigrants make us safer? N.Y. Times Mag. December (3).

Farrington, D., 1986. Age and crime. In: Tonry, M., Morris, N. (Eds.), Crime and Justice. University of Chicago Press, Chicago, IL, pp. 29-90.

Feldmeyer, B., 2009. Immigration and violence: the offsetting effects of immigrant concentration on Latino violence. Soc. Sci. Res. 38, 717-731.

Felson, R.B., Deane, G., Armstrong, D.P., 2008. Do theories of crime or violence explain race differences in delinquency? Soc. Sci. Res. 37, 624-641.

Gendreau, P., Little, T., Goggin, C., 1996. A meta-analysis of the predictors of adult offender recidivism: what works! Criminology 34, 575-607.

Hagan, J., Levi, R., Dinovitzer, R., 2008. The symbolic violence of the crime-immigration nexus: migrant mythologies in the Americas. Criminol. Pub. Policy 7, 95-112.

Hagan, J., Palloni, A., 1999. Sociological criminology and the myth of hispanic immigration and crime. Soc. Probl. 46, $617-632$.

Horton, A., 2002. Violent crimes and racial profiling: what the evidence suggests. J. Hum. Behav. Soc. Environ. 6 (4), 87-106.

Immigration Policy Center, 2008. Immigrants and Crime: Are They Connected? A Century of Research Finds that Crime Rates for Immigrants Are Lower than for Native-born. DC American Immigration Council, Washington.

INE, 2010a. Encuesta de población activa. National Institute of Statistics.

INE, 2010b. Official Population Figures for Spain. National Institute of Statistics.

Killias, M., Redondo, S., Sarnecki, J., 2011. European perspectives. In: Loeber, R., Farrington, D.P. (Eds.), The Transitions between Juvenile Delinquency and Adult Crime. Oxford University Press, New York.

Land, K.C., McCall, P.L., Cohen, L.E., 1990. Structural covariates of homicide rates: are there any invariances across time and space. Am. J. Sociol. 95, 922-962.

Lee, M.T., Martínez, R.J., Rosenfeld, R., 2001. Does immigration increase homicide? Negative evidence from three border cities. Sociol. Q. 42, 559-580.

Martinez, R., 2002. Latino Homicide: Immigration, Violence, and Community. Routledge, New York.

Martinez, R., 2010. Reduce using immigration status to address crime. In: Frost, N.A., Freilich, J.D.C. (Eds.), Contemporary Issues in Criminal Justice Policy. Policy Proposals from the American Society of Criminology Conference. Wadsworth Cengage Learning, Belmont, CA, pp. 193-204.

Martinez, R., Stowell, J.I., Lee, M.T., 2010. Immigration and crime in an era of transformation: a longitudinal analysis of homicides in San Diego neighborhoods, 1980-2000. Criminology 48 (3), 797-829.

Maruna, S., LeBel, T., Mitchell, N., Naples, M., 2004. Pygmalin in the reintegration process: desistence from crime through the looking glass. Psychol. Crime. Law 10 (3), 271-281.

McGovern, V., Demuth, S., Jacoby, J.E., 2009. Racial and ethnic recidivism risks. A comparison of postincarceration rearrest, reconviction, and reincarceration among White, Black, and Hispanic Releasees. Prison J. 89 (3), $309-327$.

Mossman, D., 1994. Assessing predictions of violence: being accurate about accuracy. J. Consult. Clin. Psychol. 62 (4), $783-792$.

Nivette, A.E., 2011. Cross-national predictors of crime: a meta-analysis. Homicide Stud. 15 (2), $103-131$.

Ousey, G.C., Kubrin, C.E., 2009. Exploring the connection between immigration and violent crime rates in U.S. cities, 1980-2000. Soc. Probl. 56 (3), 447-473.

Pratt, T.C., Godsey, T.W., 2002. Social support and homicide: a cross-national test of an emerging criminological theory. J. Crim. Justice 30, 589-601.

Reid, L.W., Weiss, H., Adelman, R.M., Jaret, C., 2005. The immigration-crime relationship: evidence across US metropolitan areas. Soc. Sci. Res. 34, 757-780.

Rice, M.E., Harris, G.T., 2005. Comparing effect sizes in follow-up studies: ROC area, Cohen's $d$, and r. Law Hum. Behav. 29 (5), 615-620.

Rumbaut, R., Ewing, W.A., 2007. The Myth of Immigrant Criminality and the Paradox of Assimilation. Immigration Policy Center, American Immigration Law Foundation, Washington.

Rumí Ibáñez, C., 2008. Boletín estadístico de extranjería e inmigración. Ministerio de Trabajo y Asuntos Sociales, Observatorio Permanente de Inmigración, Madrid.

Sampson, R.J., 2008. Rethinking crime and immigration. Contexts 7 (1), 28-33.

Sampson, R.J., Morenoff, J.D., Raudenbush, S., 2005. Social anatomy of racial and ethnic disparities in violence. Am. J. Public Health 95, 224-232.

Savolainen, J., 2000. Inequality, welfare state, and homicide: further support for the institutional anomie theory. Criminology 38 (4), 1021-1042. 
Shaw, C.R., McKay, H., 1997 [1942]. Juvenile delinquency and urban areas. In: Crutchfield, R.D., Bridges, G., Weis, J.G. (Eds.), Crime: Readins, Crime and Society, vol. 1. Pine Forge Press, Thousand Oaks, CA, pp. $138-165$. Singh, J.P., 2012. The history, development, and testing of forensic risk assessment tools. In: Grigorenko, E. (Ed.), Handbook of Juvenile Forensic Psychology and Psychiatry. Springer, New York.

Stowell, J.I., 2007. Immigration and Crime: The Effect of Immigration on Criminal Behavior. LFB Scholarly Publishing LLC, New York.

Stowell, J.I., Martínez, R.J., 2007. Displaced, dispossessed, or lawless? Examining the link between ethnicity, immigration, and violence. Aggress. Violent Behav. 12, 564-581.

Szmukler, G., 2001. Violence risk prediction in practice. Br. J. Psychiatry 178, 84-85.

Tavares, C., Thomas, G., 2010. Population and Social Conditions: Crime and Criminal Justice: Eurostat: Statistics in Focus. European Union.

Vazsonyi, A.T., Killias, M., 2001. Immigration and crime among youth in Switzerland. Crim. Justice Behav. 28 (3), 329-366.

Wright, B.R.E., Younts, C.W., 2009. Reconsidering the relationship between race and crime: positive and negative predictors of crime among African American youth. J. Res. Crime. Delinquency 46 (3), 327-352.

Wright, E.M., Benson, M.L., 2010. Immigration and intimate partner violence: exploring the immigrant paradox. Soc. Probl. 57 (3), 480-503.

Wright, J., Cullen, F.T., 2001. Parental efficacy and delinquent behavior: do control and support matter? Criminology 39 (3), 677-705. 